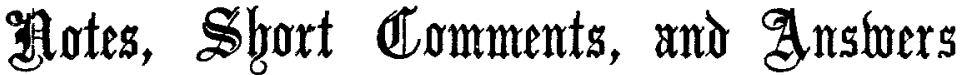 to Correspondents.}

\author{
ALPINISM. *
}

By Joseph Barcroft, C.B.E., M.A., F.R.S.

THE effects of rare air upon the human body have always had a peculiar fascination for those who make physiological inquiry their life's work. In spite of all the thought that has been spent on it in the last fifty years, the subject is as full of interest as ever. For this there are several reasons. On the intellectual side it is evident that the knowledge already gleaned has merely served to arouse a deeper interest; on the practical side the effects of rare air, ceasing to be the monopoly of a few mountaineers, have become the limiting factor of the activities of airmen. In this way the air is now vital to the world system of modern transport. Moreover, within the last decade it has become abundantly apparent that many if not all the symptoms of mountain sickness are simply due to some kind of deficiency of oxygen in the arterial blood-a condition also to be found in many pathological conditions. In such the condition of "unsaturation" of the arterial blood is, however, associated with other troubles. If, therefore, we desire to study the effect of this type of oxygen-want for the purpose of applying the knowledge to general pathology, it is best to study it in its least complicated form-namely, where unsaturation of the blood is simply brought about by insufficient pressure of oxygen in the inspired air.

$$
\text { "Oxygen-Want." }
$$

The phrase "oxygen-want" requires a word of caution. Oxygen-want in the body may arise from causes other than insufficient oxygen saturation in the arterial blood. It is not, therefore, a foregone conclusion that information tions of oxygen-want. Anoxæmia, which by convention means want of oxygen in the tissues, and not merely as its derivation implies-want of oxygen in the blood may be divided into three classes ${ }^{1}$ : (1) the anoxic type, in which the arterial blood is unsaturated; (2) the anxmic type, in which the amount of hæmoglobin per c.cm. of blood is too small; (3) the stagnant or ischæmic type, in which the blood flow is too slow.

\section{Mountain Sickness.}

Mountain sickness is typical of the anoxic type, but not at all typical of the anæmic or of the ischæmic types. Let us pass to the closer study of it. Probably if nine out of every ten persons were asked what they understood by the term "mountain sickness," they would reply that most persons on ascending high mountains, and some on ascending lower ones, vomited. Antimountain sickness has proceeded vomiting has held the attention of researchers in a gradually decreasing degree; at present if one were to ask half a dozen physiologists who have worked at over 10,000 feet what they observed, it is probable that not one of the six would mention romiting as being the first symptom to cross his mind. Yet in point of fact mountaineers who have camped at over 20,000 feet have told me that alimentary trouble is the factor which places the real limit in the altitude attainable. Before discussing the symptoms of mountain sickness in some detail let me first define the cause more particularly than $I$ have yet done.

Cause of Mountain Sickness.

As an ascent is made the barometric pressure gradually diminishes, till at the summer snow line in the Alps $(10,000$ feet) it is $540 \mathrm{~mm}$., and at the summits of the highest peaks, such as those of Mont Blanc and Monte Rosa (15,000-16,000 feet), the observer is above nearly half the atmosphere and the barometer stands at but $440 \mathrm{~mm}$. As the barometric pressure falls, so in proportion falls the pressure of oxygen which is always approximately one-fifth of the barometric pressure. The figure shows the oxygen pressure in the atmosphere plotted against the altitude in feet. The blood, however, is exposed not directly to the atmosphere, but to the air in the alveoli of the lungs. The composition of this alveolar air cannot be predicted, but measurements

* Being one of a course of advanced lectures in physiology given in the Physiological Laboratory of St. Bartholomety's Hospital, London. 1 Barcroft: Presidential address, Section I., of British Asso-
ciation, Cardiff, 1920. have been made up to about 15,000 feet in the Alps with the result shown in the figure. At sea-level, when the atmospheric air forms an oxygen pressure of $160 \mathrm{~mm}$., the oxygen in the alveolar air has a pressure of $100 \mathrm{~mm}$. In other words, the human body, by its configuration, starts with a handicap against it of about 12,000 feet.

To carry the investigation from the alveolar air to the blood which it aerates, one may ask what difference this gradually decreasing-pressure oxygen makes to the blood. That is the kernel of the whole problem of the physiology of alpinism. The lowest line in the figure shows the extent to which the blood would be oxygenated if exposed to the alveolar air of the corresponding altitude at the normal body temperature. At the sea-level 95 per cent. of the hremoglobin functions and the remaining $5 \mathrm{per}^{2}$ cent. leaves the lung without any load of oxygen. As the altitude increases the fall in oxygen pressure produces very little effect upon the amount of oxygen taken up by the arterial blood, but at about 15,000 to 18,000 feet a critical

$$
\begin{array}{cc}
\mathrm{Mrm} . \text { of } & \begin{array}{c}
\text { Percentage } \\
\text { of satura- } \\
\text { tion. }
\end{array} \\
&
\end{array}
$$

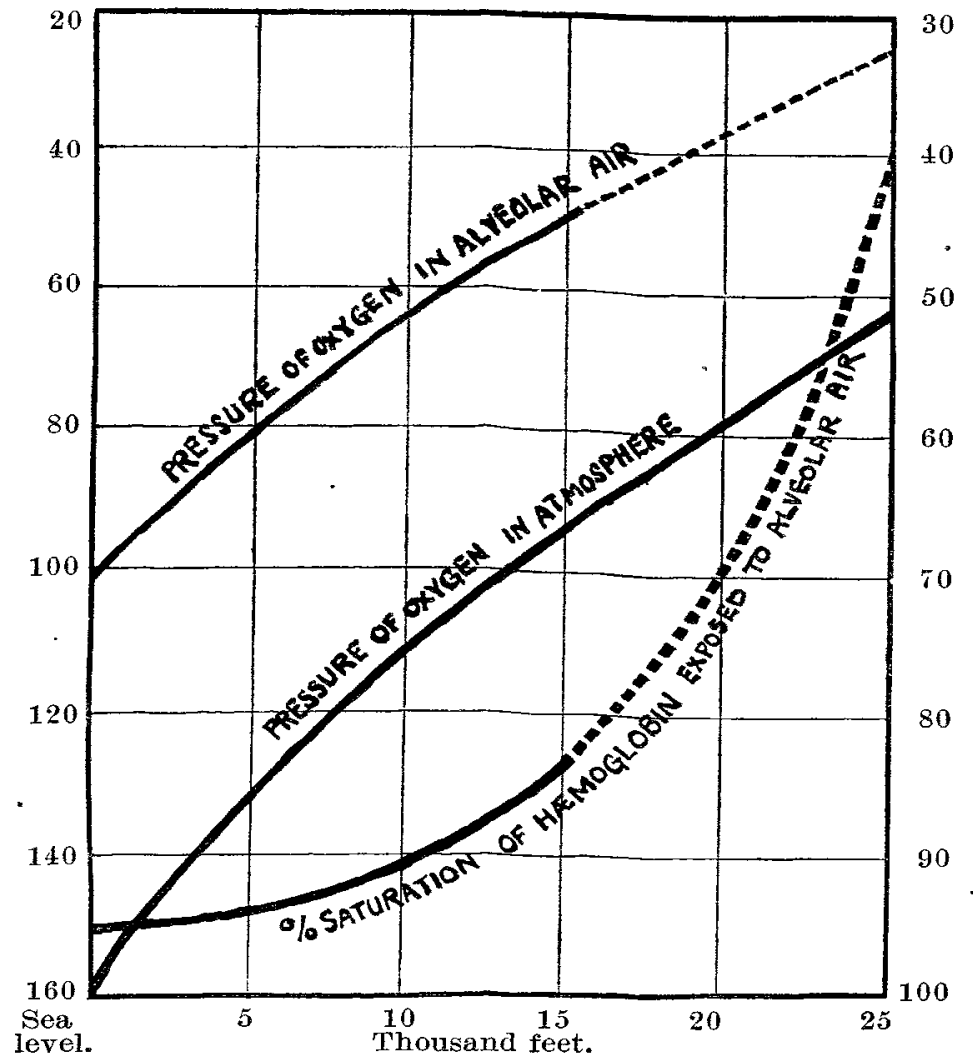

Percentage of hæmoglobin arailable for transport of oxygen from the lung if the composition of the alveolar air were as shown.

point is reached, and at altitudes above this the blood ceases to function with increasing rapidity, the line separating the hæmoglobin which does not function from that which does. This constantly, and above 18,000 feet rapidly, rising curve of " unsaturation" of the arterial blood in the physiological mountain which the body has to scale, somewhere on it is the real limit to man's faculties and activities. This curve is the real Everest.

\section{Effects of High Altitudes on the Blood.}

Since the blood permeates all the organs of the body the changes which it undergoes may first, be studied. Apart altogether from the actual amount of oxygen which the blood carries at any one time, the properties of the fluid as a wole undergo certain well-defined alterations, directed towards the preservation of an approximately constant hydrogen-ion concentration. Our knowledge is limited by the fact that actual measurements of the hydrogen-ion concentration of the blood as it exists in the body have never been made at high altitudes. Hydrogen-ion measurements have been made in chamber experiments both at Copenhagen ${ }^{2}$ and on $m y$ own blood at Cambridge. ${ }^{3}$ 'These measurements seem to agree in showing that in the chamber there is no change in the reaction of the blood which is large enough to be outside the range of error of the electrode.

2 Hasselbach and Lindhard: Zur experimentellen Physio logje des Hohenklimas, Biochem. Zeitschr., 1915, Ixviii., 295. logy, 1919, vol. liii., p. 111 . 
Measurements before incarceration and after six days in my case were for the reduced arterial blood $\mathrm{pH}=-7.35$ and $-7 \cdot 36$ respectively. Such constancy of reaction is far from factor at all events which would tend to disturb it greatlynamely, a marked fall in the concentration of free carbonic acid in the blood. To compensate for the loss of free $\mathrm{CO}_{2}$, which would tend to make the blood more alkaline, the kidney secretes alkali and so preserves the balance. In this presentation of the subject I have, as it were, stopped the film to show the most striking picture. The ends of the film are much less definite and extremely difficult of interpretation, especially as regards what is cause and what is effect ; for the moment we will leave the matter here.

The constancy in the reaction of the blood seems to carry with it one very important functional property of the hlood -namely, a constancy of the power of the hæmoglobin to unite with oxygen. So far then as the resting body at high altitudes is concerned, the blood preserves its normal power of acquiring oxygen in the lung and of giving it over reaction of the blood is muscular exercise, however, the high mountains ${ }^{356}$. The blood becomes more acid, and in two words the effect of altitude is that a much less amount of exercise will produce the same change in reaction at altitudes than at low, therefore every derangement due to exercise appears with correspondingly greater facility at high altitudes. The following data from a chamber experiment illustrate this point :-

In atmospheric

air.

4600 foot pounds. 2700 foot pounds.

Quantity of exercise in

36 mins.

Pressure of oxygen-

In aip

$87 \mathrm{~mm}$.

$160 \mathrm{~mm}$.

In arterial blood.

$48 \mathrm{nmm}$.

$100 \mathrm{~mm}$.

Exponent of hydrogenblood during rest

Ditto at end of excrcise

Ditto at end

$7 \cdot 35$

$7 \cdot 36$

$0 \cdot 08$

$0 \cdot 08$

Analysis of the blood on Monte Rosa and elsewhere seemed to show that the increase in acid is due principally to the formation of lactic acid by the muscles.

\section{The Heart.}

It is notorious that life under anoxæmic conditions puts a strain upon the heart. Any considerable amount of exercise causes evident palpitation, and here $I$ would remind you again that at high altitudes no one does take any considerable quantity of exercise. But even at rest there is usually some quickening of the pulse; not only is this quickening the direct result of oxygen-want, but the suddenness with which it is abolished by administration of oxygen is dramatic. If I may refer again to the experiment in my chamber a year ago, I would draw your attention to an occurrence which illustrates my point. One night, the fourth of my incarceration, I was lying wakefully in bed and counting $m y$ pulse from time to time; quite regularly it was within a beat or so of 86 . The time was 2 A.M. For a few moments I left the chamber and went into the outer air. In less than a minute it had dropped to 58-a normal figure for me at that time-and even mild exercise on the bicycle ergometer did not greatly raise it. It is evident, therefore, that the heart itself was not in an abnormal tate, and-apart from the anoxæmic conditions under which it was working-not unduly irritable.

Let us now turn to consider what the strain on the heart means. How are we to estimate "what the heart is doing"? I use this phrase advisedly, because I wish to avoid the phrase "work done by the heart," which has a definite physiological significance that I do not wish to convey. "The work done by the heart," or at least by the left ventricle, means approximately the volume of blood put out and the mean pressure at which it leaves the ventricle. This may be no indication of the strain put upon the heart. I will give you a case in point.

4 Barcroft: Teneriffe Expedition, Joumal of Physiology, 1912 , xlii.; p. 14

B. 206,49. of Monte Rosa Expedition, 1911, Phil. 'Trans.

B. ${ }_{6}$ Barcroft: The Respiratory Function of the Blood, chapter viii.

Barcroft, J., Bock, E. N., and Roughton, F. J. W., communicated by Physiological Societs, Las, 1921 , to be published in
Just now I have a pupil who suffers from paroxysmal tachycardia. ${ }^{7}$ His heart suddenly commences to beat at about 200 , and continues so to do for about eight hours. The quantity of blood which leaves the heart drops from 8 to 3 litres per minute, and as the arterial pressure is not greatly altered, the work done by the left ventricle would drop in the same proportion. Yet, of course, it is inconceivable that the man's heart is in reality having a rest. We must seek some other numerical estimate of the strain which the heart is sustaining. In this connexion I would refer you to the work of Rohde.

Rohde, ${ }^{8}$ working on the perfused heart, came to the conclusion that the oxygen used by the heart, which may perhaps be taken as a measure of the energy which it is transforming, varied with the product of the pulse-rate $x$ the maximal pressure at each beat. Since Rohde's time the subject has moved rapidly, and all the beautiful work on the metabolism of the heart which we associate with the heart-lung preparation ${ }^{9}$ has been carried out. Yet the simplicity of Rohde's result gives it a value which still remains, because the elements from which he builds his measure of "what the heart is doing" are such as can be estimated-the pulse and the systolic pressure. If we apply Rohde's test to the case of paroxysmal tachycardia to which I have referred a result appears quite opposite to that given by conventional measurement of the "work." The pulse in this person, normally 80 , with a systolic pressure of $120 \mathrm{~mm}$., rises to 200 with a systolic pressure of $100 \mathrm{~mm}$. Therefore there is reason to suppose that the metabolism of his heart during the attack is increased in some such ratio as 20,000 to 9600 , while the amount of blood which it distributes is less than halved.

If we apply the same reasoning to the figures which I gave for my experiment in the chamber, the pulse, as I said, dropped from 86 under anoxæmic conditions to 58 outside the chamber, the arterial pressure was 105 in the chamber. while it normally is 110 , so that the limiting figure for the product of the arterial pressure and the pulse was :In the chamber in oxygen
Ontside the chamber in 21 per cent.
oxrgen

$86 \times 105=9030$

$58 \times 110=6380$

The above figures are. of course. only approximations, because the data used are the mean arterial pressures, and not, as they should be, the svistolic pressures. Nevertheless, as approximations they illustrate the point that the heart is doing more than is normally the case during rest.

A natural inquiry arises as to what is driving the heart to its unusual exertions. The answer is, I think. the "nervous system." Dr. W. E. Dixon and I have taken many tracings in years gone by of perfused mammalian hearts which had been excised from the body and to which the supply of oxygen was gradually reduced. In no case did we observe a quickening as the result. Whether the anoxæmia causes a stimulation of the sympathetic or a diminution of the vagus tone, or both, is as yet uncertain. In the absence of any direct proof that the C.N.S. is stimulated by diminished pressure of oxygen in the blood, one rather leans to the idea that the vagus control is to some extent withdrawn. It is natural to see in this increased activity of the heart some sort of compensation to the body tor the anoxic condition of the blood. One might suppose hat by the supply of an increased volume of blood per minute the body might get the quantity of oxygen which it required, but we have no knowledge that such is the case. So far as man is concerned the data are lacking: such observations as exist were made on the cat by Doi, ${ }^{10}$ who found no increase in the volume of blood driven round the body when diminished pressure of oxygen in the inspired air led to a quickening of the pulse.

I have dwelt on the heart at rest because, little as we know about the effect of anoxremia upon it, that little is at least more than we know about its effect on the heart during exercise. Yet, of course, the fact about the heart which impresses itself upon the mountaineer is not increased pulse-rate at rest, but the increase in the pulse-rate caused by a very trifling degree of exertion. Dr. J. S. Haldane once put this point very pithily to me; he said : "Over 10,000 feet everybody is a case of disordered action of the heart."

In view of the amount of work which has been done within the last five years on disordered action of the heart and on effort syndrome, it is much to be hoped that the investigations of mountain-chimbers in this direction may early bear considerable fruit. In the meantime let me pass from the rascular system to its partner in the effort syndrome-the respiratory system. Just as there is usually some quickening of the heart at high altitudes, so there is usually some increase in the total ventilation even at rest.

Rohde: Archir f. Exp. Path. und Pharm., 1912, Bd. lxviii. p. 401 ; quoted Fespiratory Functions of the Blood, p. 90 , et sed s Starling, $H$. J., and Colleagues: Journal of Phrsiology; Erans: Ibid., xIv., p. 230 


\section{Respiration.}

More light is necessary on the cause of the mechanism by which the increase in the volume of air which enters and leaves the chest is brought about. There are two theories on the subject, for each of which there is something to be said, and which ind on two ideas largely accepted as the result of work by Haldane and Priestley, ${ }^{11}$ (1) that increased total ventilation is a function of increased hydrogen-ion concentration of the blood; (2) that the increase of hydrogen-ion concentration is necessary to produce a persecond theory is that the hydrogen-ion concentration of the blood which reaches the respiratory centre is precisely the same at high altitudes as at low ones; but that in view of the fact that the arterial blood contains somewhat less oxygen than usual, the respiratory centre is more active. The actual evidence on which a decision could be based as to which of these two theories is correct is very meagre.

The theoretical questions at issue are: (1) is the hydrogenion concentration of the blood altered (with that we have already dealt) and (2) does the degree of anoxæmia experienced in the Alps alter the respiratory rhythm?

The following data may be quoted on this subject from my chamber experiment, some of which have already been discussed. A measured quantity of work was carried out on the bicycle ergometer $(a)$ in normal air, $(b)$ at the end of six days of progressively anoxamic conditions ; the ine total ventilation were observed.

\begin{tabular}{|c|c|c|c|}
\hline- & $\begin{array}{l}\text { Work } \\
\text { performed. }\end{array}$ & $\begin{array}{c}\text { Increased } \\
\text { hydrogen-ion } \\
\text { concentration } \\
\text { of blood. }\end{array}$ & $\begin{array}{c}\text { Increased } \\
\text { total } \\
\text { rentilation. }\end{array}$ \\
\hline $\begin{array}{c}\text { Under normal } \\
\text { conditions }\end{array}$ & $\begin{array}{l}1600 \text { foot } \\
\text { pounds }\end{array}$ & $\begin{array}{c}7 \cdot 13 \cdot-7 \cdot 35 \\
=0.08\end{array}$ & $\begin{array}{l}29 \cdot 2 \longrightarrow 8 \cdot 2 \\
=21 \text { litres. }\end{array}$ \\
\hline $\begin{array}{c}\text { Under anoramic } \\
\text { conditions }\end{array}$ & $\begin{array}{l}2700 \text { foot } \\
\text { pounds. }\end{array}$ & $\begin{array}{c}7 \cdot \pm \pm-7 \cdot 36 \\
=0 \cdot 08\end{array}$ & $\begin{array}{l}32 \cdot 2-6 \cdot 1 \\
=26 \text { litres. }\end{array}$ \\
\hline
\end{tabular}

The figures show that in each case there was the same increase in hydrogen-ion concentration of the blood and almost the same increase in the total ventilation, so that they afford little help to the theory that the anoxwic conditions had rendered the centre unduly irritable. On the other hand, they show that this increase in the hydrogenion concentration of the blood had under anoxæmic conditions resulted from little more than half the effort that had been required to produce it in atmospheric air. This single experiment, and as far as $I$ know it is the only one available, would appear to favour the idea that the acidremia factor in effort syndrome is exaggerated at high altitudes, and that there is little change in the irritability of the respiratory centre. While the above experiment gives little support to the theory of increased irritability of the respiratory centre as the result of oxvgen-want, it also sheds no light on the alternative theory that the increased ventilation at rest is due to increased hydrogen-ion concentration of the blood. In the experiment in question there was no increase in total ventilation during rest.

\section{Skeletal Muscle.}

First, then, let us consider the musculature. In connexion with the muscles of the body the effect of orvgenwant, which is to me most interesting at the present time, is not much stressed by climbers-namely, undue stiffness.

It forced itself first upon me, not in the Alps, but in my own respiration chamber, when sojourning there about 15 months ago. It was mv custom to pass some portion of the afternoon taking muscular exercise in the form of liding the bicycle ergometer. The result of this exercise was to make me very stiff. Quite recently, however, the same phenomenon occurred in a much more telling way. Three subjects were testing their capacity to ro mental work in an atmosphere which was poor in oxygen, to which ther were quite unacclimatised. In one case I suggested to Dr. J.P. Lawson, of the Cambridge Psychological Department, who was carrying out the research, that they should undertake physical exercise previous to the mental tests. This they did in the shape of Swedish drill, with the unlookedfor result that they suffered acutely from stiffness, which was very definite for three days, and only disappeared entirely at the end of a week. Dr. Lawson describes the degree of stiffness in his own case as having been exceeded on the previous occasion-namely, when entirely out of training he ran eight miles without a stop on a club run. In control experiment, in which the same drill was undertaken in air after the lapse of about three months, the same subjects experienced in one case no stiffness, in two others

12 Haldane and Priestley: Journal of Physiology, 1905, xxxii., p. 225 . stiffness of a quite inferior order. No doubt the less the anoxemia the greater the amount of exercise which can be taken without subsequently paying the penalty of stiffness. Until trained, muscle, whether because it needs less oxygen or because it is supplied with more, can take almost as much exercise in normal conditions as it is capable of. Such, then, is the subjective effect of oxygenwant on muscular exercise. The principal objective effect which has been discovered is the excessive amount of lactio acid which appears in the blood. ${ }^{5}$ The possible relation between the subjective stiffness thus observed, the objective changes in turgidity, and the properties of muscle proteins grossly anoxæmic conditions form an interesting subject.

\section{Effects of High Lltitude upon the Mind.}

These effects are perhaps the most interesting of the whole series. It is a wonderful thing to see a man's whole character change as the result of exposure to a certain degree of rarity of the atmosphere, and I am sorry to say this change is always for the worse. of restraint occurs which takes different forms in different individuals, the best tempered men may become testy, the
most equible may become hilarious. I am sorry to say I have yet to meet the man who becomes pleasanter to live with when he is at 12,000 feet altitude than at the sea-level. These traits may pass into that apathy which is well known to beset climbers, and of which I could give many instances. These traits suggest some sort of intoxication, but such dependence of character on environment brings one into a much wider sphere than that of experimental physiology which limits the scope of this paper.

NATIONAL CHILDREN ADOPTION ASSOCIATION.

THIS voluntary organisation was founded by Miss Clara Andrew with the primary object of assisting children orphaned or rendered destitute by the war. Its aims were subsequently extended, and now include the formation of a National Register of those who are willing and able to guarantee the future welfare of some needy child, and of a similar register of children accepted by the committee as suitable for adoption. No premiums or weekly payments are allowed to adopters of children, and the interests of both parties are further guaranteed by references, doctors' certificates, and interviews as considered necessary. It is hoped that several hostels will shortly be established in connexion with the association; one hostel at Tower Cressy, Campden Hill, W., has been open since December, 1919 , and others have since been opened in Iondon and Southampton. The address of the association is 19, Sloanestreet, London, S.W.; subscriptions should be sent to the treasurer, National Children Adoption Association (Francis O. Rybot, Esq.), c/o London Joint City and Midand Bank, 449, Strand, London, W.C. 2.

\section{MALINGERING AND SIMUIATION}

Is a paper contributed to the Military Surgeon for May Dr. Tom A. Williams deals with Malingering and extreme vievs held in the army about malingering: the first that all complaint by the soldier not easily intellipihle by the medical officer are feigned and to be punished, the other that all detected simulations are the result of mental abnormality and are to be treated accordingly. Tis own view is that malingering is the outcome of a selfish desire for greater comfort than the enviromment supplies, a desire to be fonght by moral stimulus, and by the fear of punishment which will nuake the already uncomfortable environment still more inconvenjent. He notes in France and the United states a tondency to relicve simulators of responsibility, but thinks that in England borderland criminals are apt to be punished unless conspicunusly insane. Malingering and the exaggeration of symptoms do not occur in simple severe injuries requiring amputations, but in slighter and less definite injuries, especially roncussion cases without extemal wounds; that is why relatives and nurses must be warned not to keep awake the patient's memories of past horrors, nor to dwell on his future uncertainties. The malingerer has really a very bad time; he must be constantly on the alert to see his story is being in no way discredited, and that anxiety wears him down and he loses colour and weight, and people think this proves him ill. Such cases do become nervous and afraid of detection, and are ready to recover if some new and striking treatment gives them an excuse. One patient who had been for eight months a deaf-mute indicated one afternoon that he expected to recover. He went out for a walk, and the evening paper announced he had had a fit in a public place and on coming to himself gave out to his kindly helpers that he had recovered, thank goodness; later he wrote a letter to the doctor, thanking him for saving him from court martial, and promising to do all he could to atone for his conduet. 


\section{BRIGHTON AND THE BLIND.}

Tine Brighton Town Council has just adopted a scheme for the exercise of the powers conferred on the council under the Blind Persons Act, 1920, and has voted a grant of $£ 100$ to the local Blind Relief and Visiting Society. The object of the scheme is to keep in touch with babies born blind or with defective sight, and in the case where the home is unsuitable and where the infant shows signs of not developing there is provision for the infant being sent to the National Institute's Home for Blind Babies. Prorision is also made for children of school age, for the days, and for the marketing of goods.

\section{AN EXAGGERATED REPORT.}

OTiR Geneva Correspondent writes: Ilthough a good deal of excitement has been aroused over an incident in the surgical clinic here, no rumour current is quite so startling as that found in the English press that " the surgeon . . . extracted the beating heart of a man lying unconscious on the operating-table." The patient in question
was a suicide who had inficted on himself an incised wound. The knife had penetrated the heart and diaphragm. The thorax was opened with the idea of suturing the heart muscle, but the man was already dead. It is said that one of the assistants saw a fibrillation or contraction after adrenalin had been injected into the heart. The fact that the surgeon proceeded to open the abdomen seems to be criticised both on the ground that the patient was dead and therefore that no further procedure was proper in the operating-room, and on the ground that as a contraction of the heart had been seen the patient was not beyond hope of recovery, and therefore exploration of the abdominal cavity was unjustified. A competent commission is investigating these and similar charges and will report in due course In the meantime it should be understood that the dispute is rather on a question of technique than on a question of honour, and that whatever the result of the present inquiry no gross impropriety can be charged to the surgeon.

\section{CONJOINT BOARD OF SCIENTIFIC SOCIETIES.}

THE fourth report of this Board shors that scientific investigation is being seriously hampered by the beavy cost involved in the publication of results. An unusually large number of papers are being communicated, including many held up during the war, while the resources of the societies are insufficient at present prices to publish even the normal pre-war number. The country is thus in danger of being handicapped at a time when the rehabilitation of industry is in serious need of scientific assistance. A short abstract of the third report of the Committee on the Water Power of the Empire is included in the report of the Bcard. It is claimed that too little is being done to ascertain the total resources available, or to secure uniformity in investigation and record. It is urged that steps should be taken to convene an Imperial Trater Power Conference in London at which the various Dominions and Dependencies of the Empire should be represented. Such a conference night result in the creation of an Imperial Water Power Board with extensive powers to carry ont a comprehensive policy for stimulating coördinating, and where necessary assisting, development throughout the Empire.

The Conjoint Board of Scientific Societies has also dealt with questions relating to the formation of National Research Committees in connexion with the International Rosearch Council formed in 1919: with the collection of scientific data in the former German Colonies; and with instruction in Technical Optics. The research on glues and otber adhesives initiated by the Board as a war measure, at the instance of the Air Winistry, has now been taken ove

\section{FUGENICS EDUCATION SOCIETY.}

Ix his address at the annual meeting of the Eugenics Fincation Society on June Tth Major Leonard Darwin said that eugenics had heen called a dismal science, it should rather be described as an untried policy. If combined with an equal striving for improvements in human surroundings, it would more truly justify a hopeful outlook than anything ever yet trier. Both in genetics and eugenics further advances in knowlerlge are much needed, and many inquiries are now only held up for want of funds. The wisdom of attending to breed in the case of cattle and dogs is unirersally admitted. Experiences in the stockyard enabled us better to understand the laws of natural inheritance, but reliance on those laws does not imply that the methods of the animal breeder should be introduced into human society. Eugenists advocated nothing which was contrary to the highest roligions ideals. They had been accused of wishing to abolish love as a guide to conduct
but this was false. They wished to purify it of all harmful influences. Love was largely aroused by advantageous moral and mental qualities, and it formed the firmest foundation on which to base a eugenic policy. By promoting right ways of regarding sexual problems the moralist was often unknown to himself striving to improve the racial qualities of future generations. II but should be cautious in recommending governmental interference. If action be too bold. progress will be slow, for the wrong road will often be taken. If discussion be not bold, progress will also be slow ; for a nation cannot grope its way quickly in the darkness of ignorance. As to sterilisation, for exainple, by open discussion true conclusions would be most likely to be reached. Nearly every subject should be discussed, the occasion being properly chosen. Politicians mainly settle how far the teaching of science is to affect legislation, and this they do largely to catch votes. But the votes of future generations cannot now be caught. and their interests will receive scant attention in all democratic countries. Fugenists should discuss long and freely, and when they do advance, advance boldly. Eugenics aims at increasing the rate of multiplication of stocks above the averaye, and at decreasing that rate in the case of inferior stocks. Eugenists put moral qualities first, mental second, and physical last. When science taught us that man had been slowly evolved from some ape-like progenitor, it gave rise to a new hove that that upwrarl march would be continued, and out of that hope sprang the eugenic ideal. But science, whilst giving good grounds for hopes, also issued a grave warning concerning the danger of national deterioration from the unchecked multiplication of inferior types. A determination that such a downfall shall not be the fate of our nation if we can help it is a sentiment felt by all of us who are inspired by the eugenic ideal.

\section{SHOT BEFORE BIRTH.}

Fron Guatemala, where the use of firearms is more free than in the equable Finglish climate, there comes a curious story of how a baby was shot before birth and probably saved her nother's life at the expense of a slight flesh wound only. Dr. Joaquin Barnoyag, who relates the story $^{1}$ was a good deal puzzled by the case. His patient, aged 24, had certainly a small round wound two fingers'breadth above the umbilicus. But there were no serious symptoms, nor even was there any pain. Although the voman was only eight months pregnant, labour began on the night of her admission into hospital and a henlthy girl was born. It was not till two dars later that the doctor was asked to see a suppurating fistula on the baby's left buttock. He probed but could lind no metal. Clearly the bullet had entered the uterus-but what had happened afterwards? The $\mathbf{X}$ rays failed to discover it in mother or child. The mother's clothing showed only one hole. Completely mystified, Dr. Barnoyag asked the mother herself what had happened to the bullet and she at once admitted that she had found one in her bedclothes shortly aiter the baby was born. If there had been no pregnant uterus to catch the missile no doubt the intestines mould have been perforated and the woman would very possibly have died either from hæmorrhage or from peritonitis.

INTRATRACHEAL INSUFFLATION OF FORAI : A SIMPLE IIETHOD.

Mr. G. F. V. Anson, M.R.C.S., L.R.C.P. Lond., late senior anæsthetist to the Children's Hospital, Birmingham, and assistant anæsthetist to the ceneral Hospital in that city, who is now on his way to New Zealand, where he intends to continue his studies, writes as follows :-

"I venture to bring to the notice of the medical profession a method of giving an intratracheal insuffation of chloroform vapour. I have used the method a number of times, and have found it eminently satisfactory. The patient is anæsthetised by the usual methods, and an intratracheal catheter is passed through either the mouth or the nose. The catheter. is connected by rubber tubing to a mercury safety-valve (such as is fitted to all intratracheal apparatus), and this, in turn, to an oxygen cylinder, from which a slow stream of oxygen is allowed to flow. Into the delivery tube of a Junker apparatus is then fitted a large hypodermic needle of about the bore used with a Barker spinal anæsthetic syringe. This needle is afterwards passed into the lumen of the rubber tube ncar where it joins the intratracheal catheter. By squeezing the bulb of the Junker apparatus a slow stream of chloroform vapour is allowed to mix with the oxygen. The rate of delivery of the chloroform vapour is curtailed to within safe limits by the bore of the needle.

The method is of considerable use in such operations as diatherms of growths in the mouth and phargnx where, of course, the use of ether is contra-indicated." 